Laura Stanila, Ph.D.

West University Timișoara, Romania

\title{
LIVING IN THE FUTURE: NEW ACTORS IN THE FIELD OF CRIMINAL LAW - ARTIFICIAL INTELLIGENCE
}

\begin{abstract}
Summary
Artificial Intelligence is omnipresent in all sectors of social life, affecting, influencing, determining or facilitating our lives and decisions. Recently, a robot was "killed" by a selfdriving car. The incident reported is mentioned only for the purpose of emphasizing the need of legal regulation in this growing field. Several other incidents - autonomous vehicle crashes with human casualties - have also raised questions on the issue of criminal liability, precisely on the issue of recognizing a new actor in the field of criminal law: Artificial Intelligence.

Several initiatives at the European level and other scientific legal debates have joined in recognition of the need to acknowledge this new subject of law, or, at least to create legal tools in order to sanction Artificial Intelligence for harmful acts.

The current study aims to urge a debate on issues like electronic personality, legal and criminal liability of Artificial Intelligence, on present and future obstacles in creating an efficient legislative frame in a field in need to be properly regulated.

Old debates, such as the peril of over-criminalization or ratio of the criminalization are also reintroduced from an entirely new perspective.

The conclusions of the study point out to the necessity of outlining a set of principles and rules with specific application to Artificial Intelligence, of prompt recognition of a legal and criminal liability of Artificial Intelligence, of setting moral and legal boundaries for the human intervention and of changing the whole paradigm of legal liability by accepting this new actor: Artificial Intelligence.
\end{abstract}

Keywords: Artificial Intelligence, criminal liability, criminal policy, over-criminalization, legal liability.

\section{Introduction}

On January 6, 2019, at 7:00 pm, a self-driving Tesla Model $S$ hit and destroyed an autonomous Promobot robot model v4 in a car accident that took place in Las Vegas. ${ }^{1}$ It is neither a piece of fake news nor a script of a SF movie. It is contemporary reality. Such incidents are far from being regulated in terms of legal liability, raising serious questions on the issue of adapting the legal system to the new technological realities. As Willick noted, "the legal system is more evolutionary than revolutionary",

See a brief video available here: https://www.youtube.com/watch?v=0s4nxcleVd0 [last viewed October 10, 2019].

2 Willick M. S. Artificial Intelligence: Some Legal Approaches and Implications. AI Magazine, Vol. 4, No. 2, 1983, p. 5 . 
consequently, its changes tend to be "in response to changing cultural and economic realities, rather than the result of advanced planning" 3 . In other words, we need to find ways and techniques in order to impose legal liability (in general) and criminal liability (in particular) to Artificial Intelligence (AI), starting from the actual legal theoretical schemes. Introducing new institutions could prove to be a risky task for legislators due to inherent opposition of the public.

However, in order to address the issue of imposing criminal liability to AI, one should ask the right questions, in order to find the right answers, and these questions are:

1) Which kind of AI systems should we impose criminal liability upon?

2) Why should we impose criminal liability upon AI systems?

3) How are we going to impose criminal liability upon AI systems?

4) When? Is it necessary to impose criminal liability to AI systems now?

\begin{tabular}{|c|c|}
\hline $\begin{array}{c}\text { Whom? } \\
\text { identity }\end{array}$ & $\begin{array}{c}\text { Why? } \\
\text { necessity }\end{array}$ \\
\hline How? & When? \\
theoretical models & prematurity \\
\hline
\end{tabular}

\section{Whom to impose criminal liability upon?}

By asking this question, we aim to clarify the following aspects: identification of type of AI the imposition of criminal liability is suitable to; establishment of legal categorization of AI; identification of the solution from the perspective of legal theory of law and logics.

By making an incursion into the field of legal subjects, we can easily observe that being human is not a necessary a precondition for imposing legal or criminal liability. The theory of law offers sufficient examples according to which the legal responsibility is imposed with regard to non-human entities - the legal person, the state. Being a form of legal liability in general, criminal liability should, in principle, follow the same general rules regarding the quality of legal subjects with the particularities arising from the specificity of this branch of law.

3 Willick M. S. 1983, p. 5. 
In the field of criminal law, it is possible to impose criminal liability on some non-human entities, too. Thus, in the international law doctrine, a criminal liability of the state is accepted ${ }^{4}$.

Also, the legal person may act as a perpetrator of a crime and may be imposed criminal liability upon, and a specific punishment can be applied as a consequence.

A historical reflection on the evolution of law and criminal law shows that the failure of a legislator to identify an individual or entity as a subject of law has not prevented a legislative reform when social needs become imperative and allow the amendment of the legislation for the purpose of introducing new regulations in this regard: slaves and legal entities are eloquent examples regarding the legal recognition of certain subjects of law, which the law has not conceived of until a certain moment.

Being human is not a necessary precondition of being accorded legal personality, an obvious example being the modern business corporation ${ }^{5}$.

Also, the issue of legal liability cannot be discussed in relation with all types of AI, but only in case of "machine learning" systems. These are designed as matrices composed by cells displayed on layers, and the more cells there are, the more complex the AI system is. A "machine-learning" system learns by recognizing patterns and creating new connections between data, and thus, creates new patterns. AI "machine-learning" type system copies the neuronal synapses of the human brain (humans recognize patterns, too). The biased output that occurs sometimes is due to a false connection the system creates during the "learning process" (acting similarly to occurrence of optical illusions) or brought about by the lack quality of data entered into the system.

\subsection{What is an AI entity in legal terms?}

It is very difficult to include $\mathrm{AI}$ in one of the following categories: object (res), service, abstract entity, legal fiction (fictio juris) or person (persona). The logical analysis imposes the necessity of identifying $a b$ initio the category, in which AI is susceptible to be included: res or persona.

The term persona - person - is synonymous with that of an individual seen as a rational human being and, as a consequence, capable of self-determination. The person as a legal concept - implies the presence of consciousness and free will. Does AI fulfil any of these requirements? The temptation to fit AI into the res category is obvious, since we are talking about a machine that is created, assembled and programmed by humans. Moreover, the famous robot Sofia, in order to move from one state to

Pellet A. Can State Commit a Crime? Definitely, Yes! European Journal of International Law, Vol. 10, 1999, p. 432.

5 Chopra S., White L. Artificial Agents - Personhood. Law and Philosophy, January 2004. Available at: https://www.researchgate.net/profile/Laurence_White/publication/220837427_Artificial_ Agents_-_Personhood_in_Law_and_Philosophy/links/555c804408ae8f66f3aeec63.pdf [last viewed October 1,2019$]$. 
another at a long distance, by plane, cannot occupy a seat intended for people, it has to be disassembled and stored like ordinary luggage.

In the category of res we include the goods - useful things that can satisfy people's needs ${ }^{6}$. In the legal sense, we understand things as units that are susceptible to being individually or collectively appropriated. Real estate rights are exercised, and in particular the right to property. Goods or things cannot become holders of rights and obligations, they do not have the capacity to self-determine themselves. In some forms of AI (e.g. Sofia ${ }^{7}$ ), there is a certain self-determination, self-development capacity, and even human-specific features have been discovered - such as curiosity. Apparently, AI could be considered as belonging to res category, but sometimes the AI system makes choices and shows a certain degree of autonomy, consequently, such a categorization in the next 20-30 years will seem outdated.

Services represent the use of someone's own skills for the benefit of others, an action, a performance or a promise that is changed for a material value (benefit) ${ }^{8}$. In order to occur, the services need human actors/legal entities - providers and beneficiaries - among which are laid the foundations of a legal bond. The services do not have a material existence because their rendering becomes real when a result is expected by the beneficiary and for which he paid a price. AI cannot be classified as a service because it can self-service various services - e.g. transport, computing, marketing, analysis, etc. Or a service cannot provide another service.

Can we admit that AI entities have the status of a legal person? What would be the logical and legal foundation for such an exercise of imagination? In order to achieve this goal, we need a legal personhood.

\subsection{Theories that could explain the legal status of AI}

\section{a) The Fiction Theory}

The Fiction Theory ${ }^{9}$ has been used to justify the enforcement of corporate and collective liability. The Father of Fiction Theory seems to be Pope Innocent IV $(1243-1254)$ who named corporations by the term persona ficta ${ }^{10}$. This theory is embraced by numerous scholars - Von Savigny, Coke, Blackstone, Salmond, etc. ${ }^{11}$

6 Hamangiu C., Rosetti-Bălănescu I., Băicoianu Al. Tratat de Drept civil român [Treaty of Romanian Civil Law], Vol. I. Editura All Restitutio, București, 1996, p. 20.

7 Chung S. Meet Sophia: The robot who laughs, smiles and frowns just like us. CNN News, November 2, 2018. Available at: https://edition.cnn.com/style/article/sophia-robot-artificial-intelligence-smart-creativity/index. html [last viewed October 1, 2019].

8 Lusch R. F., Vargo S. L. (eds.), The Service-Dominant Logic of Marketing: Dialog, Debate, and Directions. M. E. Sharpe, Armonk, NY, 2006.

9 Stănilă L. Răspunderea penală a persoanei juridice [Criminal Liability of Legal Person]. Hamangiu, București, 2012, pp. 125-154.

10 Dewey J. The Historic Background of Corporate Legal Personality. Yale Law Journal, XXXV (6) 1926, p. 655.

11 Ghadas A., Ariff Z. Real or Artificial? Jurisprudential Theories on Corporate Personality. US-China Law Review, 4(5), 2007, p. 7. 
According to this theory, the legal personality of a collective entity is the result of a fiction. Since the collective entity is not a living being, the legal person cannot in fact be a person nor can have an individual personality.

The Fiction Theory could be extrapolated to electronic entities because, like legal entities, they are "invisible, immortal and can be found only in the interpretation and consideration of the law"12. Some scholars are daring to assert that the human is the only natural person while legal persons are any another kind of entity to whom the law attributes personality ${ }^{13}$. States, corporations and institutions cannot have the rights of a person, but they are seen as individuals. Therefore, the attribution of the status of persona to an electronic AI entity remains strictly at the discretion of the legislator who may or may not recognize the status of a subject of law, including criminal law. The legal personality of such an entity is a fiction, and the author of this fiction is the state.

\section{b) The Concession Theory}

The Concession Theory ${ }^{14}$ is not, in fact, an independent theory regarding the nature of legal personality, but rather a theory that attempts to explain its source ${ }^{15}$

The Concession Theory is based on the philosophical concept of national sovereignty. The State may grant or withdraw the legal personality to groups and associations, and even to other types of entities, based on the attributes of its sovereignty. For example, a legal entity is merely a creation or concession of the state, and the legal personality of the collective entity cannot exist until it is attributed by law. Therefore, an electronic entity, based on the sovereign power to legislate of the State, may be endowed by the State with legal personality, and thus becoming a person.

\section{c) The Purpose Theory}

The Purpose Theory - Zweckvermogen - proclaims the human as the only entity which may exercise rights and obligations. ${ }^{16}$ The other entities are seen as artificial persons and only act as legal instruments for the protection or achieving of real purposes. The Purpose Theory has been used to justify the legal personality attributed to collective entities that are created to achieve a legal purpose. Therefore, if we try to extrapolate this theory to AI electronic entities, $\mathrm{AI}$ is created by humans to achieve a purpose - to facilitate the unfolding of human activities, to simplify or expedite procedures - while the object of such an entity is the mathematical algorithm.

\footnotetext{
12 Ghadas A., Ariff Z. 2007, p. 8.

13 Ibid.

14 Stănilă L. 2012, pp. 125-154.

15 Dewey J. 1926, p. 666.

16 Stănilă L. 2012, pp. 125-154.
} 


\section{d) The Reality Theory}

The Reality Theory ${ }^{17}$ has also been used to explain the legal personality of a collective entity. We believe that this theory may also be extrapolated to AI-type electronic entities. According to this theory, the reality of an entity has an extra- and pre-legal dimension. The ability to acquire rights and assume obligations belongs not only to human beings, but to any entity possessing its own will and life. For example, the legal entity is a real objective entity and the law only recognizes and assigns the effects of its existence. Similarly, the electronic entity exists beyond doubt, being a human creation, and having the ability to make decisions in its more advanced forms. According to the theory of reality, the law cannot create a legal entity but only to recognize or not recognize it as such.

\subsection{The concept of legal personality - electronic personality}

\section{a) Legal or juridical personality}

The legal personality of a collective entity is an extremely difficult-to-define concept that gives rise to a series of confusions with the meaning of other philosophical-socio-legal concepts, such as status, legal capacity, ethos and, more recently, culture.

The most frequently used definition of the legal person in international doctrine is the following: "an entity - subject of rights and obligations"18. According to one part of the doctrine, the essence of the legal personality consists in the obligations an entity has. If the law imposes legal obligations on an entity, it is logical to recognize that entity as a legal entity, because it addresses a command to a legal logical unit. The difficulty comes when someone tries to explain why the legislator is doing that. And the most logical answer would be: because that legal person has free will and its obligations necessarily refer to it ${ }^{19}$.

However, in order to determine whether an entity has a legal personality, the ability to have both rights and obligations must be retained. We need to determine whether the law treats the entity as a separate legal unit. Thus, in the case of a corporation or a minor, the answer is affirmative, while in case of a cat, the answer is obviously negative ${ }^{20}$

Another definition of legal personality has been provided by French case law which, in a particular case, stated: "Legal personality is not a creation of the law, it belongs in principle to any group having the possibility of legal expression for the defense of legitimate interests, worthy of legal protection"21.

\footnotetext{
Stănilă L. 2012, pp. 125-154.

18 Radin M. The endless problem of corporate personality. Columbia Law Review, Vol. 32, 1932, p. 643.

9 Machen apud. Allgrove, 2004, p. 45.

20 Allgrove B. 2004, p. 47.

21 Streteanu F., Chiriță R. Răspunderea penală a persoanei juridice [Criminal Liability of Legal Person]. $2^{\text {nd }}$ ed., C. H. Beck, București, 2007, p. 102.
} 
A point of view was stated in the Romanian doctrine regarding the personality of the legal person, according to which "the personality of the legal person is expressed by the aim pursued, the means used in achieving this purpose, means, tacit attitudes, policies, rules and practices within the legal person and which create the overall climate of activity"22. It is the law that confers legal personality to a collective entity, while the elements indicated by the scholars refer to the decision-making apparatus and its way of managing the activity.

\section{b) Electronic Person - Electronic Personality}

The term "electronic person" was first coined in a 1967 article for LIFE magazine ${ }^{23}$ and was more recently introduced in the Draft Report with Recommendations to the Commission on Civil Law Rules on Robotics of the European Parliament's Committee on Legal Affairs. While the expression does not aim to equate artificial intelligence to humanity, it fulfils its task of drawing attention to the question of whether artificially intelligent agents should possess a legal status ${ }^{24}$.

As for artificially intelligent agents, the same rationale may apply: they would be morally entitled to a separate legal status provided they possess the capacities to act autonomously and to have subjective experiences. "A robot's autonomy can be defined as the ability to take decisions and implement them in the outside world, independently of external control or influence."25

If society begins perceiving artificially intelligent agents as autonomous actors and counterparties to transactions, as it now perceives corporations as legal entities distinct from their members, "it puts pressure on the law to give legal effect to this social perception"26. Thus, my proposal is in favour of admitting an electronic personality.

The scholars have already analysed the pros and cons of AI personhood, as follows ${ }^{27}$ :

a) Pros:

- It would allow to pool resources and centralize risks; permits artificial agents to be held liable for harm without the need to identify a responsible

22 Timofte G., Rus C. Răspunderea penală a persoanei juridice [Criminal Liability of Legal Person]. R.D.P. No. 1, București, 2005, p. 125.

23 Rosen C., Nilsson N., Bertram R. Shakey. LIFE, 1967. Available at: http://cyberneticzoo.com/ cyberneticanimals/1967-shakey-charles-rosen-nils-nilsson-bertram-raphael-et-al- american [last viewed October 1, 2019].

${ }^{24}$ Maia Alexandre F. The Legal Status of Artificially Intelligent Robots: Personhood, Taxation and Control. June 1, 2017. Dissertation developed under the supervision of Prof. Erik Vermeulen and submitted to Tilburg University to qualify for the Degree of Master of Laws (LL.M.) in International Business Law, defended on the $12^{\text {th }}$ of June, 2017, pp. 17-18. Available at: https://ssrn.com/ abstract=2985466 or http://dx.doi.org/10.2139/ssrn.2985466 [last viewed May 29, 2018].

25 Maia Alexandre F. 2017, p. 18.

26 Allgrove, 2004, p. 48.

27 Zevenbergen B., Kortz M., Schaich Borg J., Finlayson M. A., Pagallo U., Zapušek T. Appropriateness and Feasibility of Legal Personhood for AI Systems, in Bringsjord S., Tokhi M. O., Aldinas Ferreira M. I., Govindarajulu N. S. (eds.), Hybrid Worlds: Societal and Ethical Challenges, ICRES 2018 Proceedings, New York, USA CLAWAR Association Ltd, UK, 20-21 August 2018, pp. 62-63. 
individual, thus avoiding lengthy expensive and arduous process of identifying specific individuals.

- If, in the future, a general AI system is developed that is indistinguishable from a person, by what argument do we deny that system the same rights as enjoyed by a human?

b) Cons:

- The European Parliament suggests creating a collective insurance fund to cover damages arising from AI systems. As the technological trajectory of the AI is uncertain and unpredictable, it would be unwise to construct a financial compensation resources today to meet as yet unknown future needs.

- It would allow producers and owners of AI systems to shift liability to the artefact itself. This will disincentivize investment in adequate testing before deployment. AI personhood could thus result in an unsafe environment.

- It will be difficult to bring proceedings against AIs or hold them to account. An AI system has not yet the capacity to argue its case in court, appoint a lawyer to defend it or engage to reach a settlement with a plaintiff.

- Since AI does not have the capacity to suffer, nor is endowed with empathy, it is unclear how it would understand the suffering of others.

In conclusion, AI electronic/legal personhood is a sine qua non condition, which may be justified from the following perspectives:

- Technological - the boundaries of an AI system must be delimited since it could integrate and depend on external elements in order to function properly; in order to acquire legal personhood, these boundaries should be established.

- Economic - since AI is used as a tool in all areas of social life and activities, it provides benefits for the society but could also led to financial losses. It would be much easier to admit legal personhood for AI in order to facilitate the entity responsible.

- Legal - we must think of new legal institution in case the present ones are not adaptable to the specifics of AI entities.

- Moral - since AI system does not have the ability to suffer, the question of morality is useless at this stage of development, in my point of view.

\section{Why should we impose criminal liability upon AI?}

The simpler the question, the more complex the answer. We must wonder what would be the reasons for such an important intervention in the field of law. Why should we create and introduce new legal institutions - electronic personhood, 
legal/criminal liability of AI systems, new specific legal sanctions applicable in case of AI agents? In other words what is ratio criminis and ratio sanctionis in this case?

The answer is quite simple: because the society needs it! But legislators always modify present laws or adopt new ones if there are specific reasons do so. In the criminal law field, introducing the institution of criminal liability of AI systems is determined by the need to protect specific social values - the most important values for the society - from harmful acts and consequences, and since the criminal liability is the most serious form of legal liability, the intervention of the State in this regard needs to be properly and carefully considered.

Does society need a new subject of law? Does society need criminal liability of AI systems? The recent events have shown the great harmful potential of AI systems, the social values harmed or periled by AI being the ones protected by criminal tools by every national legislator: the value of life, health, body integrity, private life, etc. We observe that the condition for the intervention of the legislator in the legal system are met: social values are those protected by criminal law and the social peril of AI acts is present. Bearing in mind all these, we must proceed to the next question: finding the proper legal tools.

\section{How should we impose criminal liability upon AI? Theoretical models, schemes and tools}

By drawing a parallel with the legal liability model of corporations ${ }^{28}$, we must notice that both of the models evolved in the doctrine regarding the criminal liability of legal persons are suitable to AI systems, but with proper alterations: the anthropomorphic model and the constructivist model.

a) According to the anthropomorphic model, blameworthiness is measured by using the standards traditionally applied to individual culpability ${ }^{29}$, but the identification theory and the collective intent theory - specific to this model do not apply to AI systems in case these systems achieve a level of autonomy or self-determination (very probable in the future). Maybe an imitative anthropomorphic model is to be considered in case of AI by identifying the necessary elements of liability present in case of humans mens rea, actus reus. This could be very difficult because the human conscience could not yet be replicated by AI.

b) The constructivist model determines culpability based on the characteristics of the collective entity, on its policies, and its practices. ${ }^{30}$ According to the constructivist model, the legal person has a life of his own, a will of his own,

28 Lederman E. Models for Imposing Corporate Criminal Liability: From Adaptation and Imitation Toward Aggregation and the Search for Self-Identity. Buffalo Criminal Law Review, Vol. 4, No. 1, April 2000, pp. 641-708.

29 De Maglie C. Models of Corporate Criminal Liability in Comparative Law. Washington University Global Studies Law Review, Vol. 4, Issue 3, 2005, p. 556.

30 De Maglie C. 2005, p. 556. 
from which results also the unrestricted possibility in attributing specific mental states to the crimes. Constructivism allows labelling of an entity by assigning certain characteristics in accordance with the purpose pursued by the legislator. These characteristics become legally relevant. The constructivist model allows the identification of an AI system as a distinct actor in the social relations and an imposition of criminal liability even in the absence of a human conscience, its place being taken over by other elements to which this role or relevance is assigned.

c) The strict liability solution. Both previous models apply in case of a subjective criminal liability which is based on the culpability element and could be adapted to AI systems but need important amendments. AI systems do not have conscience (yet), cannot judge the consequences of their actions in moral terms (yet?) and sometimes do not commit acts in traditional sense of the term. The culpability element (mens rea) is difficult to identify, since these entities have no conscience. Relevant for their sanctioning are the consequences caused by their behaviour. Thus, in the case of AI systems, the strict liability theory is probably the best choice. Strict liability implies an individual or company sanctioned for their deeds, conducts and outcomes that result in damages to others, not as a consequence of a foreplanned action or careless deed. Strict liability implies a retributive blame, which distinguishes wrongdoing (essentially, the ultimate harm) from culpability (essentially, the actor's mental state) ${ }^{31}$. And even if the imposition of severe criminal sanctions in the absence of any requisite mental element has been held by many to be incompatible with the basic requirements of law and "civilized jurisprudence" ${ }^{32}$, in the case of AI agents, we can hazard to anticipate that the opposition of the doctrine will be from weak to absent. It would be almost natural to accept a strict liability in case of an agent lacking in conscience, based solely on the harmful results of its acts.

\section{Is it necessary to impose criminal liability upon AI?}

The most important question tackles the issue of prematurity in the discussion about criminal liability of AI systems. The answer must be analysed in the context of actual stage of development of AI. Since AI systems are not $100 \%$ autonomous, do not have conscience and self-determination, they apparently cannot be granted rights and imposed obligations, because it would be a nonsense. In the actual stage of development, AI reactions and involvement in social relations entirely depend of human conduct. And in this case, it is better to focus on blameworthiness of humans who designed, operated or manipulated the algorithms. Nevertheless, the research

31 Simons K. W. When is Strict Criminal Liability Just. Journal of Criminal Law and Criminology, Vol. 87, Issue 4, 1997, p. 1095.

32 Wasserstrom R. A. Strict Liability in the Criminal Law. Stanford Law Review, Vol. 12, No. 4, 1960, p. 731. 
in the area of machine-learning points to a rapid achievement ${ }^{33}$ of an "artificial" conscience.

Until AI research reaches the point of proving the existence of an artificial conscience, my proposal is in favour of a "step-by-step" approach and gradual recognition of AI systems in the field of law: initially in civil/commercial law area, and only as the final step, in criminal law area.

This would be a precautionary approach, since the criminal law system would need important legislative interventions in the sense of creating new institutions. Taking, for instance, criminal sanctions, none of the previously existing ones could be applied to AI systems. The system would need new solutions, proper and effective: unplugging, erasing of the codes, reformatting, etc. There are numerous details to be addressed.

\section{Conclusions: can we or should we impose criminal liability on AI?}

The conclusions of the present study are, likewise, presented in the form of a question: can we or should we impose criminal liability on AI? The answer to this final question is - certainly, yes, we can. As demonstrated in the first part of the study, the State through its legislator may grant legal personhood to AI systems and, with extensive effort, it may even create a specific model to impose criminal liability upon AI. Nevertheless, the answer to the second part of this final question is, in my opinion, no, we should not do it at present. The arguments for it focus mainly on elements of technical development of AI, as they present themselves at the time of this discussion. AI systems are not autonomous self-conscient entities yet, and AI reactions depend on several factors, which are predetermined and selected by humans in the design or operating process. Other arguments focus on the legislative element, or, rather, lack of it, since legislators need to conceive a new and efficient legal frame. Old traditional schemes and institutions are not suitable for the specificity of AI systems.

Proactivity is the most important element in the whole discussion. We need to be prepared for the moment when AI systems will resemble humans in the terms of conscience, but rushing things and accepting a new AI subject in the field of law could have disastrous consequences for the law systems. Elements like embodiment or nature of AI system, the degree of autonomy, the function of AI system, the environment, the nature of interaction between AI and humans ${ }^{34}$ should be carefully analysed. At this very moment, no one could assess the mid-term or

33 McLain C. Can Artificial Intelligence Be Conscious? March 27, 2018. Available at: https:// medium.com/hummingbird-ventures/can-artificial-intelligence-be-conscious-e316c2ac4769 [last viewed October 10, 2019].

34 Van den Hoven van Genderen R. Do We Need New Legal Personhood in the Age of Robots and AI? In: Corrales M., Fenwick M., Forgó N. (eds.), Robotics, AI and the Future of Law. Perspectives in Law, Business and Innovation. Springer, Singapore, 2018, p. 20. 
long-term effects of these developments on the legal system and more research is still to be done.

\section{LITERATURE}

1. Chung S. Meet Sophia: The robot who laughs, smiles and frowns just like us. CNN News, November 2, 2018. Available at: https://edition.cnn.com/style/article/sophia-robot-artificialintelligence-smart-creativity/index.html [last viewed October 1, 2019].

2. Chopra S., White L. Artificial Agents - Personhood. Law and Philosophy, January 2004. Available at: https://www.researchgate.net/profile/Laurence_White/publication/ 220837427_Artificial_Agents_-_Personhood_in_Law_and_Philosophy/links/555c 804408ae8f66f3aeec63.pdf [last viewed October 0, 2019].

3. De Maglie C. Models of Corporate Criminal Liability in Comparative Law, Washington University Global Studies Law Review, Vol. 4, Issue 3, 2005.

4. Dewey J. The Historic Background of Corporate Legal Personality. Yale Law Journal, XXXV (6), 1926.

5. Ghadas A., Ariff Z. Real or Artificial? Jurisprudential Theories on Corporate Personality. USChina Law Review, 4(5), 2007.

6. Hamangiu C., Rosetti-Bălănescu I., Băicoianu Al. Tratat de Drept civil roman [Treaty of Romanian Civil Law], Vol. I, Editura All Restitutio, București, 1996.

7. Lederman E. Models for Imposing Corporate Criminal Liability: From Adaptation and Imitation Toward Aggregation and the Search for Self-Identity. Buffalo Criminal Law Review, Vol. 4, No. 1, April 2000.

8. Lusch R. F., Vargo S. L. The Service-Dominant Logic of Marketing: Dialog, Debate, and Directions. M. E. Sharpe, Armonk, NY, 2006.

9. Maia Alexandre, F. The Legal Status of Artificially Intelligent Robots: Personhood, Taxation and Control. June 1, 2017. Dissertation developed under the supervision of Prof. Erik Vermeulen and submitted to Tilburg University to qualify for the Degree of Master of Laws (LL.M.) in International Business Law, defended on the $12^{\text {th }}$ of June, 2017. Available at: SSRN: https://ssrn.com/abstract=2985466 or http://dx.doi.org/10.2139/ssrn.2985466, [last viewed May 29, 2018].

10. McLain C. Can Artificial Intelligence Be Conscious? March 27, 2018. Available at: https:// medium.com/hummingbird-ventures/can-artificial-intelligence-be-conscious-e316c2ac4769, [last viewed October 10, 2019].

11. Pellet A. Can State Commit a Crime? Definitely, Yes! European Journal of International Law, Vol. 10, 1999.

12. Radin M. The endless problem of corporate personality. Columbia Law Review, Vol. 32, 1932.

13. Rosen, C., Nilsson, N., Bertram, R. Shakey. LIFE, 1967. Available at: http://cyberneticzoo. com/cyberneticanimals/1967-shakey-charles-rosen-nils-nilsson-bertram-raphael-et-alamerican, [last viewed October 01, 2019].

14. Simons K. W. When is Strict Criminal Liability Just. Journal of Criminal Law and Criminology, Vol. 87, Issue 4, 1997.

15. Stănilă L. Răspunderea penală a persoanei juridice [Criminal Liability of Legal Person]. Hamangiu, București, 2012. 
16. Streteanu F., Chiriță R. Răspunderea penală a persoanei juridice [Criminal Liability of Legal Person], $2^{\text {nd }}$ ed., C. H. Beck, București, 2007.

17. Timofte, G., Rus, C. Răspunderea penală a persoanei juridice [Criminal Liability of Legal Person]. R.D.P., No. 1, 2005, Bucureşti.

18. Van den Hoven van Genderen R. Do We Need New Legal Personhood in the Age of Robots and AI?. In: Corrales M., Fenwick M., Forgó N. (eds.), Robotics, AI and the Future of Law. Perspectives in Law, Business and Innovation. Springer, Singapore, 2018.

19. Wasserstrom R. A. Strict Liability in the Criminal Law. Stanford Law Review, Vol. 12, No. 4, 1960.

20. Willick M. S. Artificial Intelligence: Some Legal Approaches and Implications. AI Magazine, Vol. 4, No. 2, 1983.

21. Zevenbergen B., Kortz M., Schaich Borg J., Finlayson M. A., Pagallo U., Zapušek T. Appropriateness and Feasibility of Legal Personhood for AI Systems, in Bringsjord S., Tokhi M. O., Aldinas Ferreira M. I., Govindarajulu N. S. (eds.), Hybrid Worlds: Societal and Ethical Challenges, ICRES 2018 Proceedings, New York, USA, 20-21 August 2018, CLAWAR Association Ltd, UK, 20-21 August 2018.

\section{Other sources}

1. A Promobot robot was killed by a self-driving Tesla car. Video material available at: https:// www.youtube.com/watch?v=0s4nxcleVd0 [last viewed October 10, 2019].

2. Chung S. Meet Sophia: The robot who laughs, smiles and frowns just like us. CNN News, November 2, 2018. Available at: https://edition.cnn.com/style/article/sophia-robot-artificialintelligence-smart-creativity/index.html [last viewed October 1, 2019]. 